Article

\title{
Investigation of Steam Treatment on the Sorption Behavior of Rice Straw Pellets
}

\author{
Xiao He ${ }^{1, *}$, Lianjun Wang ${ }^{1}$ and Anthony Lau ${ }^{2}$ \\ 1 Jiangsu Key Laboratory of Chemical Pollution Control and Resources Reuse, School of Environmental and \\ Biological Engineering, Nanjing University of Science and Technology, Nanjing 210094, China; \\ wanglj@njust.edu.cn \\ 2 Department of Chemical and Biological Engineering, University of British Columbia, 2360 East Mall, \\ Vancouver, BC V6T 1Z3, Canada; akplau@ubc.ca \\ * Correspondence: xhe@njust.edu.cn
}

Received: 21 September 2020; Accepted: 12 October 2020; Published: 16 October 2020

check for updates

\begin{abstract}
Agricultural residue is a readily available biomass source for making biofuels. However, complex structure along with low calorific value makes it reluctant to be utilized. This necessitates the pretreatment of biomass to improve its accessibility. In this study, rice straws were treated with saturated steam at $180-200^{\circ} \mathrm{C}$ for $5-10 \mathrm{~min}$ and pelletized. Results indicated that the pretreatment process could effectively improve the calorific values and enhance the hydrophobicity of the rice straws. The steam explosion process changed the content of chemical components in the biomass materials. With the increase of reaction temperature and retention time, the content of cellulose, hemicelluloses and lignin declined. Comparedwith the raw materials, there was an increase in the calorific value from $16.24 \mathrm{MJ} / \mathrm{kg}$ to $17.26 \mathrm{MJ} / \mathrm{kg}$ for the steam treated straws. For moisture sorption test under the condition of $30^{\circ} \mathrm{C}$ and $90 \%$ relative humidity, the equilibrium moisture content dropped from $21 \%$ for untreated straw pellets to $14.2 \%$ for the steam treated straw pellets treated at $200{ }^{\circ} \mathrm{C}$ for $10 \mathrm{~min}$. Moisture adsorption rate reduced along with the increase in steam temperature and retention time. This study demonstrated that steam explosion performed an effective way to improve the characteristics of agricultural residues.
\end{abstract}

Keywords: steam explosion; straw; pellet; calorific value; moisture sorption

\section{Introduction}

Renewable resource such as biomass appears to be an attractive feedstock in today's world, due to its sufficiency and criteria air pollutant emissions as compared to fossil fuels. Biomass used as clean energy to generate electricity and heat has become an important element of sustainability nowadays [1]. A large amount of biomass in the form of crop residues is harvested annually in China. However, the utilization of the crop straws has been low over the past decades. Furthermore, a portion of straws were combusted directly in the field, which caused severe air pollution [2]. It is essential to utilize the agricultural straws to meet the increasing demand for renewable energy and minimize the environmental pollutions.

The recalcitrant structure and low energy content of agricultural biomass make it difficult to be converted into various biofuels. In biorefinery industry, pretreatment is applied to facilitate the conversion process [3]. Steam explosion is considered as one of the most efficient and environmental-friendly pretreatment processes for improving the fuel properties of lignocellulosic biomass [4]. The physicochemical properties of biomass are modified by depolymerizing lignin, hydrolyzing hemicelluloses content, and breaking down the connected structure of hemicelluloses and lignin $[5,6]$. The crystallinity and accessibility of cellulose is improved significantly as a result of 
steam treatment $[7,8]$. Many researchers have reported the increasing yield of bioethanol from crop residues using steam explosion [9-11]. Zhou et al. investigated that the biogas produced from rice straw increased by $51 \%$ after steam explosion [12]. This phenomenon was also found from steam treated rape straw by Vivekanand [13] and corn stover by Shi [14]. Moreover, many attempts have been made to enhance the production of various biofuels by steam explosion including biohydrogen, biobutanol, biodiesel, and biomethane in the past decades [2,15-18]. In contrast, pelletization of crop residues to make solid fuel has not received comparable concern.

The utilization of agricultural residues as solid biofuel is hampered by their physical characteristics. The most concern is the calorific value and moisture sorption behavior of biomass through the supply chain. The raw crop straws are bulky with high moisture content, resulting in low energy content. Pretreatment is essential to generate high quality fuel, which is favorable for combustion. Previous studies showed that steam explosion could increase the calorific value of woody biomass by up to $26 \%$ and enhance the adhesiveness efficiently for bioconversion $[19,20]$. In order to facilitate the handling of biomass, pelletization is usually applied to make densified products with low moisture content [21]. However, the combustion efficiency of agricultural pellets decreases as a result of moisture uptake from the surrounding environment during transportation and storage. Furthermore, it provides an ideal environment for microorganism growth, thus leading to the deterioration and breakdown of pellets [22,23]. According to Lam et al., the steam treated Douglas fir pellets exhibited better hydrophobic when compared to the untreated pellets [19]. Tooyserkani et al. reported the equilibrium moisture content of steam treated Pine, Spruce, and Douglas fir wood decreased in humid environment [20]. Reduction of moisture adsorption after steam explosion was also found for wheat straw, which was speculated as a result of the decrease of hemicelluloses content [24].

Rice straw as an inexpensive and abundant crop biomass is largely produced in China. There is a need to explore the potential of rice straw for solid biofuel. The residues from harvest can be used in the form of powder or pellets for combustion. Problems pertinent to the storage and utilization of straw pellets include moisture affinity, quality deterioration, and low combustion energy. Based on the literature review, steam explosion could improve the characteristics of woody biomass to produce solid biofuel. The objective of this study was to evaluate the effect of steam explosion on the rice straw. Properties of untreated and steam treated straw materials including compositional characteristic, calorific value and moisture adsorption were characterized, measured, and compared. Findings from this research may be beneficial to design a process to produce high quality solid biofuel.

\section{Materials and Methods}

\subsection{Materials}

Rice straws collected from eastern China were used as experimental materials. The straws were cut into small pieces with an average length of $2 \mathrm{~cm}$. The samples were then stored in a sealed plastic bag at $4{ }^{\circ} \mathrm{C}$ before the test.

\subsection{Steam Explosion Pretreatment}

The straw samples were steam treated in a high-pressure steam explosion unit consisting of reactor chamber, steam generator, and monitoring device. Steam was generated in a boiler to reach the desired temperature and transferred to the steam chamber. Typical temperatures and retention time of steam explosion range from 160 to $260^{\circ} \mathrm{C}$ and seconds to a few minutes [18]. Within this range, hemicellulose hydrolyzed to sugars and lignin can betransformed to some extent, thus making the steam explodedmaterials more degradable. From the literature, the characteristics of agricultural straws can be well improved after steam explosion at $180-220^{\circ} \mathrm{C}$ for $30 \mathrm{~s}$ to $10 \mathrm{~min}[2,9,12]$. In this study, saturated steam with the temperature of $180{ }^{\circ} \mathrm{C}$ and $200{ }^{\circ} \mathrm{C}$ was applied (corresponding to the pressure of 1.0 and $1.6 \mathrm{MPa}$ ), along with the retention time of $5 \mathrm{~min}$ and $10 \mathrm{~min}$. The profile of temperature and pressure was measured and logged automatically. At the end of each run, steam was 
released suddenly, and the straw samples were removed to an open chamber. The treated straws were then collected in a plastic bag and stored in a cool place for further measurements.

\subsection{Chemical Characterization}

Chemical compositions of both untreated and steam treated straws were measured. The content of ash, cellulose, hemicelluloses, and lignin were determined according to the National Renewable Energy Laboratory method (NREL) $[25,26]$. The calorific values of treated and untreated rice straws were measured by the oxygen bomb calorimeter (Parr 6200, Moline, IL, USA). Analysis was made in three replicates, and the average values of the three replicates were used in this study.

\subsection{Moisture Sorption}

The untreated and steam treated straw samples were conditioned to moisture content of $10 \%$, and ground using a grinding mill to pass through a 40-mesh screen. Each ground sample was compressed in the Pellet Press to make the pellet with diameter of $6.35 \mathrm{~mm}$ and length of $20 \mathrm{~mm}$. The cylinder was heated to $80^{\circ} \mathrm{C}$ and a maximum compaction force of $126 \mathrm{MPa}$ was set to produce the pellets. Afterwards, the pellets were cooled and stored in sealed bottles for further analysis.

Moisture adsorption tests were conducted in a controlled humidity chamber (HCP50, Swedesboro, NJ, USA) for pellets made from both untreated and steam treated samples at temperature of $30^{\circ} \mathrm{C}$ and different relative humidity (60-90\%) settings. Before each adsorption test, all pellets were dried in an oven at $60^{\circ} \mathrm{C}$ for $72 \mathrm{~h}$. The dried samples were then placed in a dish in the humidity chamber with pre-set temperature-humidity values. The weight of the samples was monitored and recorded every 5 min until reaching the equilibrium moisture content. The weight was measured by a digital balance (WANT Digital Weighing Scale, Jiangsu, China) with $0.01 \mathrm{~g}$ precision. After each test, the moisture content of the pelletized samples was determined in triplicate in a forced-air convection oven at $103^{\circ} \mathrm{C}$ for $24 \mathrm{~h}$ according to ASAE Standards S358.2 [27]. Three replicates were performed for each test.

The moisture adsorption rate was estimated by the ASAE formulation for thin-layer drying [28]:

$$
\frac{M-M_{e}}{M_{i}-M_{e}}=e^{-k t}
$$

where $M$ is the instantaneous moisture content (decimal, dry basis), $M_{e}$ is the equilibrium moisture content (decimal, dry basis), $M_{i}$ is the initial moisture content (decimal, dry basis), $k$ is the moisture adsorption constant $\left(\mathrm{min}^{-1}\right)$, and $t$ is time $(\mathrm{min})$.

\subsection{Statistical Analysis}

The data were expressed as the average of triplicates and based on the dry mass. The standard deviation was stated.

\section{Results and Discussion}

\subsection{Effect of Steam Explosion on Chemical Properties}

Table 1 lists the elemental analysis of untreated and steam-exploded rice straws. The carbon content increased from $42.14 \%$ for untreated samples to $46.47 \%$ for most severe steam treated samples, while the content of hydrogen decreased from $5.60 \%$ to $5.35 \%$ respectively. Furthermore, the percentage of oxygen reduced from $51.45 \%$ to $47.40 \%$ with higher temperature and longer retention time. The ratio of $\mathrm{C}$ and $\mathrm{H}$ increased from 7.53 to 8.69 as a result of the hydroxyl removal after steam explosion. It was assumed that the formation of carbon dioxide and water might lead to the reduction of hydrogen and oxygen. 
Table 1. Ultimate analysis and calorific value of untreated and steam treated rice straw.

\begin{tabular}{cccccccc}
\hline \multirow{2}{*}{ Treatment } & $\mathbf{C}$ & $\mathbf{H}$ & $\begin{array}{c}\mathbf{N} \\
\text { (\% Dry Matter) }\end{array}$ & $\mathbf{S}$ & $\mathbf{O}$ & $\begin{array}{c}\text { Calorific } \\
\text { Value (MJ/kg) }\end{array}$ \\
\hline \multirow{2}{*}{ Untreated } & Average & 42.14 & 5.60 & 0.67 & 0.14 & 51.45 & 16.24 \\
& Standard deviation & 0.13 & 0.04 & 0.03 & 0.01 & 0.20 & 0.07 \\
\hline \multirow{2}{*}{$180^{\circ} \mathrm{C}, 5 \mathrm{~min}$} & Average & 42.82 & 5.48 & 0.68 & 0.07 & 50.95 & 16.47 \\
& Standard deviation & 0.08 & 0.06 & 0.02 & 0.004 & 0.09 & 0.05 \\
\hline \multirow{2}{*}{$180^{\circ} \mathrm{C}, 10 \mathrm{~min}$} & Average & 43.86 & 5.62 & 0.62 & 0.07 & 49.83 & 16.51 \\
& Standard deviation & 0.11 & 0.02 & 0.02 & 0.008 & 0.08 & 0.15 \\
\hline \multirow{2}{*}{$200^{\circ} \mathrm{C}, 5 \mathrm{~min}$} & Average & 45.63 & 5.51 & 0.72 & 0.08 & 48.06 & 16.95 \\
& Standard deviation & 0.05 & 0.02 & 0.01 & 0.007 & 0.10 & 0.09 \\
\hline \multirow{2}{*}{$200^{\circ} \mathrm{C}, 10 \mathrm{~min}$} & Average & 46.47 & 5.35 & 0.71 & 0.07 & 47.40 & 17.26 \\
& Standard deviation & 0.04 & 0.05 & 0.04 & 0.002 & 0.11 & 0.21 \\
\hline
\end{tabular}

The measured calorific values of straw samples are also listed in Table 1. The calorific value of 16.24 MJ/kg was measured with untreated straw samples. The calorific value increased by up to a maximum of about $6.3 \%$ after steam explosion at $200{ }^{\circ} \mathrm{C}$ for $10 \mathrm{~min}$ as compared to the untreated samples. Results indicated the calorific values increased as a result of higher steam temperature and longer retention time. It revealed that steam pretreatment could enhance the energy content of rice straws. During steam explosion, small hydrocarbon molecules with low energy density were volatilized, which resulted in the increase of energy density in the remaining samples. Furthermore, carbonization of samples as a result of steam treatment might contribute to higher energy content.

The main organic components of straw samples under different treatment conditions are shown in Figure 1. It is noted that the steam temperature and retention time had a significant influence on lignocellulosic composition. The hemicellulose content of untreated straw sample was $25.2 \%$ originally, which reduced dramatically to $7.3 \%$ after steam explosion at $200{ }^{\circ} \mathrm{C}$ for $10 \mathrm{~min}$. The large degradation of hemicellulose when comparing to celluloses and lignin might be owing to its amorphous nature [29]. The decomposition temperature of hemicellulose is much lower than that of cellulose and lignin. Since hemicellulose is thermally unstable, it can be hydrolyzed into monosaccharides and oligosaccharides. Decrease in hemicelluloses at higher steam temperature has also been reported in other studies [30]. Lignin was also observed to decrease with increasing treated temperature and retention time. It was reported that steam treatment might lead to partly degradation of lignin. Moreover, the crosslinking of polysaccharide chains and polymerization of degraded compounds from lignin might occur during treatment process [24]. In contrast, there was a slight decrease in cellulose, which was speculated as a result of crystallinity of cellulose. It was also demonstrated by the other researchers that hemicelluloses could be removed largely, while cellulose and lignin were partially dissolved at high temperature [31-33].

The influence of steam pretreatment on ash content was also investigated and plotted in Figure 1. The ash content of the straw samples was $6 \%$ before treatment, which was much higher than that of woody biomass (usually less than $1 \%$ ) $[19,20]$. Worth noting is that there was no apparent change in ash content and the percentage increased slightly after steam explosion at $200{ }^{\circ} \mathrm{C}$ for $10 \mathrm{~min}$. This phenomenon might be due to the partly degradation of hemicelluloses and cellulose. Increase in ash content is in accordance with the findings of some researches, as it was reported owing to the loss of other components in the biomass [20,29]. However, some studies reported reduction in ash content after steam pretreatment. Han et al. reported the ash content of wheat straw reduced to around $1.6-4 \%$ at different treatment conditions, which might be attributed to the removal of ash through steam release [34]. 


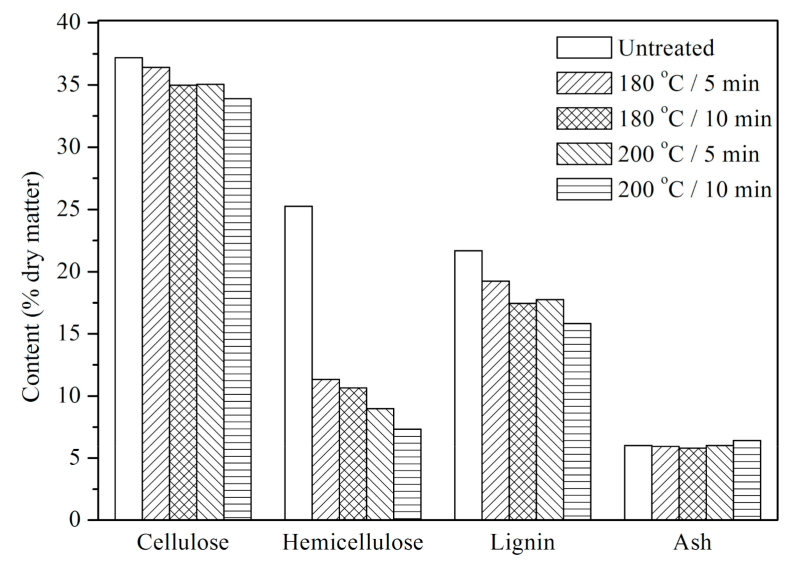

Figure 1. Main organic and ash composition of rice straws under different treatment conditions.

\subsection{Effect of Steam Explosion on Moisture Adsorption}

Figure 2 illustrates the moisture adsorption of pelletized samples with/without treatment in the humidity chamber at $30{ }^{\circ} \mathrm{C}$ and $90 \%$ relative humidity.

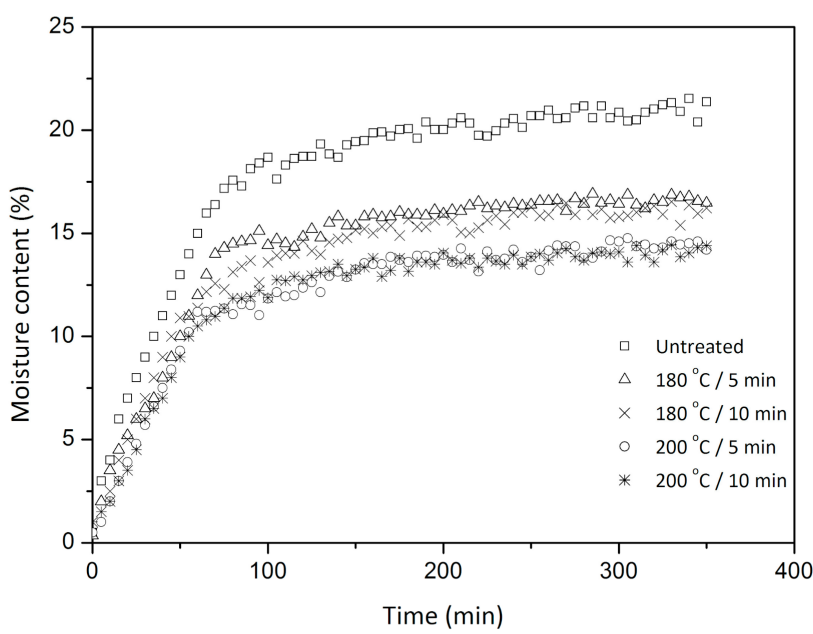

Figure 2. Moisture adsorption of untreated and steam treated pelletized samples in the controlled chamber set at $30^{\circ} \mathrm{C}$ and $90 \%$ relative humidity.

The pellets made from untreated straw exhibited the most hygroscopic behavior, as it reached the equilibrium moisture content of $21 \%$ after $360 \mathrm{~min}$. In contrast, the equilibrium moisture content of the pellets made from steam exploded straw treated at $180{ }^{\circ} \mathrm{C}$ for $5 \mathrm{~min}$ and $10 \mathrm{~min}$ was $17.1 \%$ and $16.5 \%$, respectively. After steam treatment at $200{ }^{\circ} \mathrm{C}$, the straw pellets approached the lower equilibrium moisture content of around $14 \%$ regardless of retention time. Results indicated the straw pellets became less hydrophilic after steam treatment. Decrease in equilibrium moisture content was accompanied by increase in treatment temperature and retention time, which is in accordance with the findings of other researches [35,36]. It was speculated that reduction in hydroxyl functional groups decreased the affinity of steam exploded samples to moisture [20]. In addition, increase in crystallinity could also result in the less adsorption of water [24]. Table 2 shows the equilibrium moisture content of pellets made from untreated and steam treated materials read off the moisture adsorption curves. The coefficient of moisture adsorption rate is also listed in Table 2. The moisture adsorption rate was $0.0220 \mathrm{~min}^{-1}$ for untreated samples. The constant decreased to values ranging from $0.0177 \mathrm{~min}^{-1}$ to $0.0188 \mathrm{~min}^{-1}$ after steam treatment at $200{ }^{\circ} \mathrm{C}$ for $10 \mathrm{~min}$ and $180^{\circ} \mathrm{C}$ for $5 \mathrm{~min}$, respectively. 
Table 2. Equilibrium moisture content and moisture adsorption constant of pellets made from untreated and steam treated straws in the controlled chamber set at $30^{\circ} \mathrm{C}$ and $90 \%$ relative humidity.

\begin{tabular}{ccccc}
\hline \multirow{2}{*}{ Treatment } & \multicolumn{2}{c}{ Equilibrium Moisture Content (\%) } & \multicolumn{2}{c}{ Moisture Adsorption Rate (min $\left.{ }^{-1}\right)$} \\
\cline { 2 - 5 } & Average & Standard Deviation & Average & Standard Deviation \\
\hline Untreated & 21.0 & 0.12 & 0.0220 & 0.002 \\
$180^{\circ} \mathrm{C}, 5 \mathrm{~min}$ & 17.1 & 0.14 & 0.0188 & 0.005 \\
$180^{\circ} \mathrm{C}, 10 \mathrm{~min}$ & 16.5 & 0.20 & 0.0181 & 0.002 \\
$200^{\circ} \mathrm{C}, 5 \mathrm{~min}$ & 14.3 & 0.08 & 0.0178 & 0.001 \\
$200{ }^{\circ} \mathrm{C}, 10 \mathrm{~min}$ & 14.2 & 0.15 & 0.0177 & 0.003 \\
\hline
\end{tabular}

The moisture adsorption behavior of the pellets made from untreated straw and steam-exploded straw (treated at $200{ }^{\circ} \mathrm{C}$ for $10 \mathrm{~min}$ ) at a constant temperature of $30^{\circ} \mathrm{C}$ and different relative humidity of $60-90 \%$ was investigated and plotted in Figure 3. The equilibrium moisture content was observed to increase with relative humidity. The equilibrium moisture content of steam exploded sample was $6.1 \%$ at $60 \%$ relative humidity, and it increased to $14.2 \%$ at $90 \%$ relative humidity. This large growth in moisture content along with a mild increase in relative humidity indicated the effect of capillary condensation [37]. By comparison, the equilibrium moisture content of pellets made from untreated straw was much higher under the same relative humidity, ranging from $11.2 \%$ to $21 \%$ with relative humidity of $60 \%$ to $90 \%$. Another important point is that the curve at higher relative humidity had higher adsorption rate with steeper slope at the initial stage for both samples.
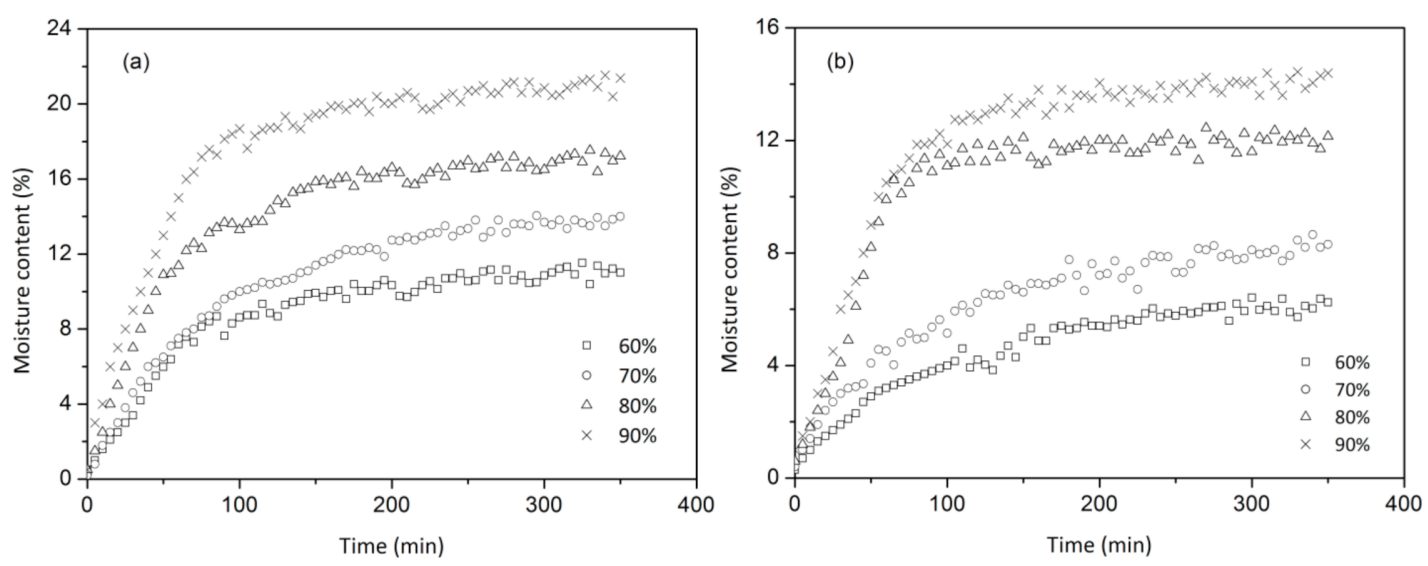

Figure 3. Moisture adsorption of: (a) pellets made from untreated straw; (b) pellets made from steam exploded straw treated at $200^{\circ} \mathrm{C}$ for $10 \mathrm{~min}$, under condition of $30^{\circ} \mathrm{C}$ and four levels of relative humidity.

Table 3 lists the moisture adsorption rate of untreated samples versus steam explode samples. The constant of pellets made from untreated straw ranged from $0.0106 \mathrm{~min}^{-1}$ to $0.0220 \mathrm{~min}^{-1}$ with increasing relative humidity, which were higher than those of steam treated materials under the same experimental conditions. It revealed that the moisture affinity of straw reduced significantly after steam explosion. 
Table 3. Equilibrium moisture content and moisture adsorption constant of untreated and steam exploded straw samples in the controlled chamber set at $30^{\circ} \mathrm{C}$ and different relative humidity.

\begin{tabular}{|c|c|c|c|c|c|}
\hline \multirow{2}{*}{$\begin{array}{c}\text { Relative } \\
\text { Humidity (\%) }\end{array}$} & & \multicolumn{2}{|c|}{$\begin{array}{l}\text { Equilibrium Moisture } \\
\text { Content (\%) }\end{array}$} & \multicolumn{2}{|c|}{$\begin{array}{l}\text { Moisture Adsorption Rate } \\
\qquad\left(\min ^{-1}\right)\end{array}$} \\
\hline & & Untreated & $200^{\circ} \mathrm{C}, 10 \mathrm{~min}$ & Untreated & $200{ }^{\circ} \mathrm{C}, 10 \mathrm{~min}$ \\
\hline \multirow{2}{*}{60} & Average & 11.2 & 6.1 & 0.0106 & 0.00839 \\
\hline & Standard deviation & 0.08 & 0.12 & 0.001 & 0.0005 \\
\hline \multirow{2}{*}{70} & Average & 13.9 & 8.4 & 0.0141 & 0.0100 \\
\hline & Standard deviation & 0.21 & 0.11 & 0.001 & 0.001 \\
\hline \multirow{2}{*}{80} & Average & 17.3 & 12.1 & 0.0187 & 0.0152 \\
\hline & Standard deviation & 0.14 & 0.19 & 0.001 & 0.001 \\
\hline \multirow{2}{*}{90} & Average & 21.0 & 14.2 & 0.0220 & 0.0177 \\
\hline & Standard deviation & 0.12 & 0.15 & 0.002 & 0.003 \\
\hline
\end{tabular}

\section{Conclusions}

The effect of steam explosion on the properties of rice straws was investigated. Results showed that the energy value and hydrophobicity of straws were enhanced. Increase in carbon content along with decrease in oxygen was found after steam treatment. It was demonstrated that the calorific value of steam exploded straw increased by $6.3 \%$ at the maximum after treated at $200{ }^{\circ} \mathrm{C}$ for $10 \mathrm{~min}$, indicating the increased energy content of the treated materials. The content of hemicelluloses was significantly reduced through steam explosion, whereas cellulose content changed slightly. Moreover, there was no apparent removal of ash content. The moisture affinity of rice straws reduced after steam explosion. Higher steam temperature and longer retention time resulted in less hydrophilic materials. The moisture adsorption rate of the pellets made from steam exploded straw was slower than the pellets made from untreated straw. In the controlled chamber set at $30{ }^{\circ} \mathrm{C}$ and $90 \%$ relative humidity, the equilibrium moisture content reduced from $21 \%$ for the pellets made from untreated straw to $14.2 \%$ for the pellets made from most severity steam exploded sample. Accordingly, the moisture adsorption constant of pelletized samples decreased from $0.022 \mathrm{~min}^{-1}$ (untreated) to $0.0177 \mathrm{~min}^{-1}\left(200^{\circ} \mathrm{C}, 10 \mathrm{~min}\right.$ ). Results from this research can be used to provide information on the storage and process of agricultural biomass during the supply chain.

Author Contributions: Conceptualization, L.W. and A.L.; formal analysis, X.H.; funding acquisition, X.H. and A.L.; methodology, X.H. and A.L.; Writing-Original draft, X.H.; Writing-Review and editing, L.W. and A.L. All authors have read and agreed to the published version of the manuscript.

Funding: This research was supported by Natural Science Foundation of Jiangsu Province (No. BK20150779), and the Natural Sciences and Engineering Research Council of Canada.

Conflicts of Interest: The authors declare no conflict of interest.

\section{References}

1. Cai, J.; He, Y.; Yu, X.; Banks, S.W.; Yang, Y.; Zhang, X.; Yu, Y.; Liu, R.; Bridgwater, A.V. Review of physicochemical properties and analytical characterization of lignocellulosic biomass. Renew. Sustain. Energy Rev. 2017, 76, 309-322. [CrossRef]

2. Yu, Q.; Liu, R.; Li, K.; Ma, R. A review of crop straw pretreatment methods forbiogas production by anaerobic digestion in China. Renew. Sust. Energ. Rev. 2019, 107, 51-58. [CrossRef]

3. Rezania, S.; Oryani, B.; Cho, J.; Talaiekhozani, A.; Sabbagh, F.; Hashemi, B.; Rupani, P.F.; Faraji, H. Different pretreatment technologies of lignocellulosic biomass for bioethanol production: An overview. Energy 2020, 199, 117457. [CrossRef]

4. Bhutto, A.W.; Qureshi, K.; Harijan, K.; Abro, R.; Abbas, T.; Bazmi, A.A.; Karim, S.; Yu, G. Insight into progress in pre-treatment of lignocellulosic biomass. Energy 2017, 122, 724-745. [CrossRef] 
5. Yan, W.; Acharjee, T.C.; Coronella, C.J.; Vásquez, V.R. Thermal pretreatment of lignocellulosic biomass. Environ. Prog. Sustain. Energy 2009, 28, 435-440. [CrossRef]

6. Rajput, A.A.; Zeshan; Visvanathan, C. Effect of thermal pretreatment on chemical composition, physical structure and biogas production kinetics of wheat straw. J. Environ. Manag. 2018, 221, 45-52. [CrossRef] [PubMed]

7. Auxenfans, T.; Crônier, D.; Chabbert, B.; Paës, G. Understanding the structural and chemical changes of plant biomass following steam explosion pretreatment. Biotechnol. Biofuels 2017, 10, 36. [CrossRef] [PubMed]

8. Aski, A.L.; Borghei, A.; Zenouzi, A.; Ashrafi, N.; Taherzadeh, M.J. Effect of steam explosion on the structural modification of rice straw for enhanced biodegradation and biogas production. Bioresources 2019, 14, 464-485.

9. Zhao, S.; Li, G.; Zheng, N.; Wang, J.; Yu, Z. Steam explosion enhances digestibility and fermentation of corn stover by facilitating ruminal microbial colonization. Bioresour. Technol. 2018, 253, 244-251. [CrossRef]

10. Damay, J.; Boboescu, I.; Duret, X.; Lalonde, O.; Lavoie, J.M. A novel hybrid firstand second generation hemicellulosic bioethanol production processthrough steam treatment of dried sorghum biomass. Bioresour. Technol. 2018, 263, 103-111. [CrossRef]

11. Kossatz, H.L.; Rose, S.H.; Viljoen-Bloom, M.; Van Zyl, W.H. Production of ethanol from steam exploded triticale straw in a simultaneous saccharification and fermentation process. Process. Biochem. 2017, 53, 10-16. [CrossRef]

12. Zhou, J.; Yan, B.; Wang, Y.; Yong, X.Y.; Yang, Z.H.; Jia, H.; Jiang, M.; Wei, P. Effect of steam explosion pretreatment on the anaerobic digestion of rice straw. RSC Adv. 2016, 6, 88417-88425. [CrossRef]

13. Vivekanand, V.; Ryden, P.; Horn, S.J.; Tapp, H.S.; Wellner, N.; Eijsink, V.G.H.; Waldron, K.W. Impact of steam explosion on biogas production from rape straw in relation to changes in chemical composition. Bioresour. Technol. 2012, 123, 608-615. [CrossRef]

14. Shi, Q.; Li, Y.; Li, Y.; Cheng, Y.; Zhu, W. Effects of steam explosion on lignocellulosic degradation of, and methane production from, corn stover by a co-cultured anaerobic fungus and methanogen. Bioresour. Technol. 2019, 290, 121796. [CrossRef]

15. Huzir, N.M.; Aziz, M.A.; Ismail, S.; Abdullah, B.; Mahmood, N.A.N.; Umor, N.; Nooh, S.M. Agro-industrial waste to biobutanol production: Eco-friendly biofuels for next generation. Renew. Sustain. Energy Rev. 2018, 94, 476-485. [CrossRef]

16. Manochio, C.; Andrade, B.; Rodriguez, R.P.; Moraes, B.S. Ethanol from biomass: A comparative overview. Renew. Sustain. Energy Rev. 2017, 80, 743-755. [CrossRef]

17. Sarkar, N.; Ghosh, S.K.; Bannerjee, S.; Aikat, K. Bioethanol production from agricultural wastes: An overview. Renew. Energy 2012, 37, 19-27. [CrossRef]

18. Zheng, Y.; Zhao, J.; Xu, F.; Li, Y. Pretreatment of lignocellulosic biomass for enhanced biogas production. Prog. Energy Combust. Sci. 2014, 42, 35-53. [CrossRef]

19. Lam, P.S.; Sokhansanj, S.; Bi, X.T.; Lim, C.J.; Melin, S. Energy Input and Quality of Pellets Made from Steam-Exploded Douglas Fir (Pseudotsugamenziesii). Energy Fuels 2011, 25, 1521-1528. [CrossRef]

20. Tooyserkani, Z.; Sokhansanj, S.; Bi, X.; Lim, C.J.; Lau, A.; Saddler, J.; Kumar, L.; Lam, P.S.; Melin, S. Steam treatment of softwood particles to produce torrefied material. Appl. Energy 2013, 103, 514-521. [CrossRef]

21. Adapa, P.; Tabil, L.; Schoenau, G.; Opoku, A. Pelleting characteristics of selected biomass with and without steam explosion pretreatment. Int. J. Agric. Biol. Eng. 2010, 3, 62-79.

22. Shaw, M.; Karunakaran, C.; Tabil, L. Physicochemical characteristics of densified untreated and steam exploded poplar wood and wheat straw grinds. Biosyst. Eng. 2009, 103, 198-207. [CrossRef]

23. Biswas, A.K.; Yang, W.; Blasiak, W. Steam pretreatment of Salix to upgrade biomass fuel for wood pellet production. Fuel Process. Technol. 2011, 92, 1711-1717. [CrossRef]

24. Han, G.; Cheng, W.; Deng, J.; Dai, C.; Zhang, S.; Wu, Q. Effect of pressurized steam treatment on selected properties of wheat straws. Ind. Crop. Prod. 2009, 30, 48-53. [CrossRef]

25. Sluiter, A.; Hames, B.; Ruiz, R.; Scarlata, C. Determination of Structural Carbohydrates and Lignin in Biomass; Technical Report NREL/TP-510-42618; Laboratory Analytical Procedure (LAP); NREL: Colorado, CO, USA, 2012.

26. Sluiter, A.; Hames, B.; Ruiz, R.; Scarlata, C. Determination of Ash in Biomass; Technical Report NREL/TP-510-42622; Laboratory Analytical Procedure (LAP); NREL: Colorado, CO, USA, 2008. 
27. American Society of Agricultural Engineers (ASAE). S358.2-Moisture Measurement-Forage; ASAE Standard: St. Joseph, MI, USA, 2010.

28. American Society of Agricultural Engineers (ASAE). S448.2-Thin-Layer Drying of Agricultural Crops; ASAE Standard: St. Joseph, MI, USA, 2014.

29. Iroba, K.L.; Tabil, L.G.; Sokhansanj, S.; Dumonceaux, T.J. Pretreatment and fractionation of barley straw using steam explosion at low severity factor. Biomass Bioenergy 2014, 66, 286-300. [CrossRef]

30. Chen, H.; Liu, J.; Chang, X.; Chen, D.; Xue, Y.; Liu, P.; Lin, H.; Han, S. A review on the pretreatment of lignocellulose for high-value chemicals. Fuel Process. Technol. 2017, 160, 196-206. [CrossRef]

31. Wang, K.; Jiang, J.; Xu, F.; Sun, R.; Baird, M.S. Influence of steam pressure on the physic-chemical properties of degraded hemicelluloses obtained from steam-exploded lespedeza stalks. Bioresources 2010, 5, 1717-1732.

32. Kurokochi, Y.; Sato, M. Steam treatment to enhance rice straw binderless board focusing hemicellulose and cellulose decomposition products. J. Wood Sci. 2020, 66, 1-8. [CrossRef]

33. Tang, Y.; Chandra, R.P.; Sokhansanj, S.; Saddler, J.N. Influence of steam explosion processes on the durability and enzymatic digestibility of wood pellets. Fuel 2018, 211, 87-94. [CrossRef]

34. Han, G.; Deng, J.; Zhang, S.; Bicho, P.; Wu, Q. Effect of steam explosion treatment on characteristics of wheat straw. Ind. Crop. Prod. 2010, 31, 28-33. [CrossRef]

35. Acharjee, T.C.; Coronella, C.J.; Vásquez, V. Effect of thermal pretreatment on equilibrium moisture content of lignocellulosic biomass. Bioresour. Technol. 2011, 102, 4849-4854. [CrossRef] [PubMed]

36. Medic, D.; Darr, M.; Shah, A.; Rahn, S. Effect of torrefaction on water vapor adsorption properties and resistance to microbial degradation of com stover. Energy Fuels 2012, 26, 2386-2393. [CrossRef]

37. Mihranyan, A.; Strømme, M. Capillary condensation of moisture in fractal pores of native cellulose powders. Chem. Phys. Lett. 2004, 393, 389-392. [CrossRef]

Publisher's Note: MDPI stays neutral with regard to jurisdictional claims in published maps and institutional affiliations. 